\title{
Mahatma Gandhi's Ahimsa: The Path Forward for Nonviolent Peaceful Resistance
}

\author{
Navodita Pande \\ 'Juriya Jan', 270, Lakhanpur, Vikas Nagar, Kanpur, Uttar Pradesh, India \\ Corresponding author: navoditapande@googlemail.com
}

Received: 16 June, 2019

Revised: 19 Oct., 2019

Accepted: 24 Nov., 2019

\begin{abstract}
Non-violence is abstention from violence or principle thereof. Gandhi's ethical formulation of ahimsa acts as the cornerstone of his revolutionary and ideological contestations. Simultaneously, the question of ahimsaic goodness has to be made to confront the conflicting claims of human vulnerability or fragility. The paper argues that Gandhian ahimsa can be understood in two ways: first, as a form of nonviolent protest and second, as a form that protests against violence. In either case, ahimsa can be identified as a concept constituted within and occasioned by the rhetoric of struggle, particularly struggle against the state-whether it be the Transvaal government in South Africa, the colonial state in India, or the increasingly centralized post-colonial Indian state. The modern authoritarian state cannot be the ideal political system for Gandhi much as Gandhi argues for deindustrialization, demilitarization and deburaucratization. He called his ideal democratic state as gram swarajya.
\end{abstract}

Keywords: Nonviolence, Gandhism, developmental state, Ramrajya, gram swarajya

In the wake of the agitation going on across the nation to showcase their disagreement with the current government on Citizenship Amendment Act and other such decisions, this paper studies why there needs to be nonviolent resistance and why Gandhi is ever more relevant. The paper argues that nonviolence as a tool of the strong is a potent weapon to fight injustices and democracy which is degrading the very fabric of the country. Peace is negatively defined as the absence of violent orientations and conditions and positively as the presence of harmonious effects and circumstances (Sharma, 1999). Nonviolence is abstention from violence or the principle thereof. Peace is a state of tranquility or quiet; freedom from civil disturbance; freedom from oppressive thoughts or emotions; harmony in personal relations; a pact or agreement to end hostilities between those at war or in enmity; to be quiet or silent or free from strife or disorder (ibid).

\section{LITERATURE REVIEW}

\section{Ahimsa Paramo Dharmah}

Like most ascetic-ethical practices, Gandhian ahimsa is principally a renunciative project that proceeds, to borrow Nussbaum's words, "by placing the most important things, things such as personal achievement, politics, and love, under our control" (Gandhi, 1996). Gandhi's politicization of ahimsa-as

\footnotetext{
How to cite this article: Pande, N. (2019). Mahatma Gandhi's Ahimsa: The Path Forward for Nonviolent Peaceful Resistance. Int. J. Peace, Edu. and Deve., 7(02): 89-93.

Source of Support: None; Conflict of Interest: None
} 
I will argue later-is articulated in similar terms, as an appeal for national self-sufficiency in the face of the many temptations of modernity. As he writes in Hind Swaraj: We notice that the mind is a restless bird, the more it gets the more it wants, and still remains unsatisfied. The more we indulge our passions the more unbridled they become. Our ancestors, therefore, set a limit to our indulgences. They saw that happiness was largely a mental condition. In a typical gesture, Gandhi dissociates "happiness" from a pull to pleasure and, instead, reclaims it as the ethical effect of sacrifice or abstinence (ibid).

As Nussbaum reminds us, the Kantians similarly privilege "the rational element in us" as the agency which mediates between that which is "messy, needy, uncontrolled, rooted in the dirt and standing helplessly in the rain" and that which is "divine, immortal, intelligible, unitary, indissoluble, ever self-consistent and invariable". In Gandhi's modifications of Kantian thought, the work of rational self-defense is conducted through the relentless discipline of self-constraint, which, as Richard Gregg puts it, "gives a sense of control over exterior forces". By postulating ahimsa as a safeguard against the riskiness of "exterior forces," Gandhi can, of course, also characterize it as an ethico-political activity that nonviolently counteracts all disabling human/national passivity to external happenings. Gandhi's ethical formulation of ahimsa, thus, acts as the cornerstone of his revolutionary and ideological contestations. At the same time, the question of ahimsaic goodness has to be made to confront the conflicting claims of human vulnerability or fragility. Again, in Nussbaum's words:

... on the other side of this pursuit of self-sufficiency, complicating and constraining the effort to banish contingency from human life, was always a vivid sense of the special beauty of the contingent and the mutable.... The question of life- saving thus becomes a delicate and complicated one .... It becomes, in effect, the question of the human good: how can it be reliably good and still be beautifully human (1993).

Something of Gandhi's aspiration to moral reliability emerges in an early definition of ahimsa: 'Ahimsa requires deliberate self-suffering, not a deliberate injuring of the supposed wrong- doer... In its positive form, ahimsa means the largest love, the greatest charity" (Iyer, 1987). Here, Gandhi presents ahimsa as a condition in which love is universal and suffering has an ontological and ideational priority/ status. Both of these themes-universal love and suffering-eventually come into conflict with the structures of individuation within which affection and pain are ultimately situated. The Gandhian discipline of universal love-for it is that incorporates a critique of all transgressive manifestations of affective intimacy. Selective love, Gandhi argues, obstructs the ethical obligation to "love those whom we consider as vile men and women" (ibid). One way to countermand Gandhi's ethical imperative in favor of altruism appears in Levinas's assertion of "proximity" as the primary ethical motivation for responsibility toward the Other. For Levinas, unlike Gandhi, proximity or the face-to-face relationship cannot be subsumed into a totality. Its ethical appeal, instead, inheres in forms of immediacy which are-to recall Nuss- baum again-grounded within the etymology of luck. Thus we come to a whole lot of questions that surround Ahimsa, and Gandhian principles in today's light.

\section{Research Questions}

The questions that this paper answers are:

$\odot$ What is Gandhian philosophy of Ahimsa?

$\odot$ What is Gandhian idea of ideal state?

$\odot$ What is Gandhian notion of democracy?

\section{Methodology}

The study is based on secondary sources and review of works done by other authors and researchers to understand the deeper meanings of such definitions.

\section{Findings and Analysis}

\section{Ahimsa as the weapon}

As a category and practice of resistance, Gandhian ahimsa can be understood in two ways: first, as a 
form of nonviolent protest and second, as a form that protests against violence. In either case, ahimsa can be identified as a concept constituted within and occa- sioned by the rhetoric of struggle, particularly struggle against the state-whether it be the Transvaal government in South Africa, the colonial state in India, or the increasingly centralized postcolonial Indian state. By foregrounding the state as the occasion for, or object of, ahimsaic struggle, I wish to draw attention to the frequently unacknowledged anarchist content of Gandhian ahimsa. Subsequent to the postcolonial domestication of Gandhi as a signifier of peace and tolerance, critical reappraisals of his thought tend to situate his ahimsaic adaptations primarily within a genealogy of nonviolent speculation. It is both impossible and unnecessary to discount Gandhi's pacifist inheritance. At the same time, and as writers like Joan Bondurant and Peter Marshall recognize, Gandhi's ahimsaic postulations seek a parallel legacy within Indian and other traditions of "disobedience." It is useful to recall Gandhi's own insistence on ahimsa as a type of disobedience where he says, "in India . . . we cease to co-operate with our rulers when they displease us. This is passive resistance in Hind Swaraj. In a sense, Gandhi's ahimsaic intervention into anarchist thought, marked by his bringing of "passivity" to bear upon acts of "resistance," begins with his identification of violence at the heart of all monopolies of force, whether they be the state, capitalism, or, as I have been arguing, the patriarchal family. All economic monopolies, in his view, sustain and consolidate the violent apparatus of governmentality. He says in Harijan "Simple homes from which there is nothing to take require no policing: the palaces of the rich must have strong guards to protect them against dacoits. So must huge factories". Relatedly, he is uncompromising in his characterization of government as the embodiment of violence: "The State represents violence in a concentrated and organized form. The individual has a soul, but the State is a soulless machine, it can never be weaned from violence to which it owes its existence" (Iyer, 1987). Within these paradigms of power, the act of struggling against the state becomes the ahimsaic expression of (nonviolent) protest against violence.

Thus, the state and struggles against it must all be nonviolent and peaceful. Gandhi also gives his views on what is an ideal state and democracy.

\section{Ideal state}

Gandhian idealism would, therefore, require a certain degree of de-technologicalization of the high-tech massive industries, and would emphasize appropriate technology that is determined by native interests and local conditions, and not by outside experts for considerations of outside or external industry and economy (Naidu, 1987). Gandhian economy advocates heavy reliance upon agriculture, instead of mass industrialization. But this agriculture has to be small scale and dependent upon local natural conditions, resources and indigenous technology (ibid). There is enough evidence in the industrialized world today to point out that agricultural surpluses have created the curse of abundance. However, Gandhism would be deeply involved in fighting in the Third World the curse of agricultural poverty, especially food scarcity, the products of centuries of colonial exploitation and neglect. Food self-sufficiency, in the Gandhian view, would be important not only in terms of providing the basic need of the people, but also in terms of not having to depend upon basic imports from outside the community. The Gandhian ideal, therefore, is a village economy that is self sufficient in agriculture and food, and is selfregulated in the context of ecological harmony and swadesi (indigenous) goods.

To Gandhism, therefore, the modern authoritarian state cannot be the ideal political system. Gandhism propounds the opposite as the ideal - a political system that consists of a small community and a small territory, and that is redeemed of big economy, big military and big politics. Gandhian ideal political system is, therefore, the village republic that is economically and politically self-governed. Gandhi calls it the panchayati raj. Once Gandhi called his ideal system an ocean with a centrifugal centre occupied by the individual/village.

The achievement of the ideal village republic in 
the Third World would mean the abandonment of the craze to copy the big industrial state and the recreation or resuscitation of the local community that has existed for a long time in such societies. The establishment of the panchayati raj in the industrialized states would imply the degovernmentalization through deindustrialization, demilitarization and debureaucratization to achieve decentralization of economic and political power out of the consequent social-economic forces; in a word true "participatory democracy".

The Gandhian political ideal of self-sufficient and autonomous village republic cannot be achieved without the ideal society that has been built upon certain cultural values and social behaviours. The following five elements could be considered as the fundamentals of the Gandhian ideal society: satya (Truth), Prema (Love), Seva (Service), Sarvodaya (Universal well-being) and Ahimsa (Non-Violence). His views on an ideal democracy are similar.

\section{Ideal democracy}

There is need to dispel the illusion that a parliamentary democracy is not in tune with Gandhi's philosophy (Chaturvedi \& Rai, 2008). What has come to be ultimately by Gandhi is the imminent goal of 'swarajya' which is an improved state of representative parliamentary democracy; Gandhi's theory of the 'ideal state' can be comprehended better if the same can be viewed in the hierarchy of three stages:

$\odot$ The Ultimate ideal Gandhi had no love for the organized institutions of political power.

$\odot$ As such the ideal political order of Gandhi's perception would be a stateless society.

$\odot$ Gandhi describes his ideal stateless order as Ramrajya.

This is not synonymous to Hindu Raj but refers to a divine State wherein external controls over individual's inner conscience are removed to their fullest possible extent. Gandhi calls such a stage, a state of enlightened anarchy. By anarchy, however, he does not refer to a state of lawlessness but to a well ordered system, wherein individual would acquire such perfection so as to became completely self- regulated requiring no external controls, or institutions representing coercive authority. When a perfect individual, realizes the ideal of ahimsa on his perfection, dedicate himself to the ultimate truth and ultimate reason and inner conscience pervade his entire conduct, external controls become not only undesirable but also of no consequence In such a State every individual would be his own ruler but his rule will never be a hindrance to his neighbour, for the realization of spiritual unity of all human beings would make his submission for the collective good an essential ingredient of his own identification as an individual. Thus in ultimate analysis, the ideal political of order of Gandhi's perception would envisage a self sufficient, self governed autonomous individual.

To Gandhi centralization of political power amounts to himsa (ibid). Thus, the basis of his ideal democratic order is decentralization of political power. He called his ideal democratic order as gram-swarajya. In the scheme of Gram Swarajya, as he envisaged, every village would be a republic or panchayat having full powers. For this every village would be required to be self-sustained and capable of managing its affairs even to the extent of defending itself against the whole world, This would, however, not exclude dependence, on and willing help from neighbours or from the world. Such social order must naturally be based on truth and non-violence which, in his opinion, would not be possible without a living belief in God. This was the democracy as idealized by Gandhiji.

\section{CONCLUSION}

Thus it maybe said peace and nonviolence have many dimensions - inner-outer, individualcollective, and this worldly-other worldly. Peace and non-violence are relevant to existence at the levels of the body, the mind, and the spirit. The achievement of peace and nonviolence at the spiritual level is of utmost importance. Once spiritual peace and nonviolence are attained, bodily and mental peace and nonviolence follow effortlessly just as branches and leaves get their nourishment when the roots are watered properly. Peace and nonviolence exist 
at different levels within and outside the person, starting with the individual and then moving on to the family, neighbourhood, community, nation, and world at large. In the conceptions of peace and nonviolence are included not only the living beings, but also physical and cosmic environments that complete our worldview in this life.

\section{REFERENCES}

Chaturvedi, M.S. and Rai, S. 2008. Democracy: The Gandhian Paradigm. The Indian Journal of Political Science, 249-260.
Gandhi, L. 1996. Concerning Violence: The Limits and Circulations of Gandhian "Ahisma" or Passive Resistance. Cultural Critique, 35: 105-147.

Naidu, M.V. 1987. The Gandhian Vision of the Ideal Political Society. Peace Research, 68-81.

Nussbaum, Martha. 1993. The Fragility of Goodness: Luck and Ethics in Greek Tragedy and Philosophy. Cambridge: Cambridge UP.

Sharma, S. 1999. Peace and Nonviolence in the Indian Religious Tradition. Peace Research, 31(1): 58-65. 
